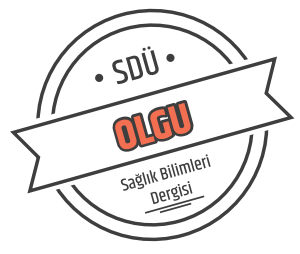

Sdü Sağlık Bilimleri Enstitüsü Dergisi / Cilt 8 Sayı 2 / 2017

\title{
Retroperitoneal Ancient Schwannoma: A Case Report and Review of Literature
}

\section{Retroperitoneal Ancient Schwannom}

\author{
E. Elif Özkan'1, İ. Metin Çiriş̧², A. Yeşim Yalçın', Erol Eroğllu ${ }^{3}$ \\ ${ }^{1}$ Suleyman Demirel Univercity, Departmant of Radiation Oncology, Isparta, Turkey. \\ ${ }^{2}$ Suleyman Demirel Univercity, Departmant of Patology, Isparta, Turkey. \\ ${ }^{3}$ Suleyman Demirel Univercity, Deparment of Oncologic Surgery, Isparta, Turkey.
}

\section{Objective}

We present here a case of retroperitoneal ancient schwannoma and review this rare entity under the guidence of recent literature.

\section{Case}

An 66-year-old men admitted to our clinic with a retroperitoneal mass in plain radiography without any symptoms. F-18 FDG PET- CT scan revealed 26 x 19 mm regularly contoured hypodense hypermetabolic nodular lesion in right inferior quadrant leaning on ileopsoas muscle. Histopathology from a tru-cut biopsy and was reported as mixoid spindle cell tumor revealing mixoid liposarcoma. The patient underwent total excision of the retroperitoneal mass. Postoperative pathologic diagnosis was reported as ancient schwannoma. The patient was recommended observation without any adjuvant treatment and is free of recurrence in postoperative 10th month.

\section{Conclusion}

Ancient Schwannomas are originating from perineural Schwann cells. They are accepted as benign, but some may be mistakenly termed malignant. As they are well encapsulated, recurrences following complete surgical excision are uncommon.

Anahtar kelimeler: Ancient, Retroperiton, Schwannom

\section{Amaç}

Çalışmamızda retroperitonal ancient schwannom tanısı alan bir olguyu literatür eşliğinde sunmayı amaçladık.

\section{Olgu}

Altmış altı yaşında bir erkek hasta şikayeti olmaksızın düz grafide saptanan retroperitoneal kitle ile hastanemize başvurdu. F-18 FDG PET- CT görüntülerinde iliopsoas kasının sağ inferiorunda 26 x 19 mm düzgü sınırlı hipodense hipermetabolik nodüler lezyon izlendi. Tru-cut biyopsi ile elde edilen histopatoloji miksoid liposarkomayı düşündüren miksoid iğ hücreli tümör olarak raporland1. Hastaya total eksiyon uygulandı. Operasyon patolojisi ancient schwannom olarak değerlendirildi. Adjuvan tedavisiz takip önerilen hasta operasyon sonrası 10. ayda rekürrenssiz izlemde.

\section{Sonuç}

Ancient Schwannom periferal schwan hücrelerinden köken alır. Genellikle benign olarak kabul edilmekle birlikte bazen yanlışlıkla malign olarak değerlendirilebilir. İyi kapsüllü oldukları için komplet rezeksiyon sonrası nüks genellikle beklenmez.

Anahtar kelimeler: Ancient, Retroperiton, Schwannom

\section{Introduction}

Schwannomas are benign tumors of peripheral nerve sheath. They ususally occur as solitary encapsulated mass. It has a slight female predominance mostly seen between the second and fifth decades of life(1). The frequently seen clinical sites are head and neck and extremities. Retroperitoneal schwannoma is rare except the cases in associated with von Recklinghausen's disease (2). Only $0.5 \%$ to $12 \%$ of retroperitoneal tumors and $0.5 \%$ to $5 \%$ of all schwannomas are retroperitoneal scwannomas. Malignant transformation is infrequent. The term "ancient schwannoma" refers to the degenerative changes, which develops with increasing duration (age) (3) Nuclear atypia may also be present in these tumors and may be mistaken for malignant change. Complete surgical resection results in cure and recurrences are uncommon. We describe a retroperitoneal ancient schwannoma case treated at our Institute.

\section{Case Report}

A retroperitoneal mass was realised in plain radiography of 66-year-old men without any symptoms. Clinical examination was normal.

An F-18 FDG PET- CT scan revealed 26 x 19 mm regularly contoured hypodense hypermetabolic nodular lesion in right inferior quadrant leaning on ileopsoas muscle with anterior contiguity (SUV max: 3.49) (Figure 1a $-1 \mathrm{~b}$ ). The patient
DOI: $10.22312 /$ sdusbed.266081

Müracaat tarihi: 15.11 .2016
Kabul tarihi: 02.03 .2017
Yazışma Adresi / Corresponding: Emine Elif Özkan,
Suleyman Demirel Univercity, Departmant of Radiation Oncology, Isparta, Turkey.
Tel: 02462212000
E-mail: ozkanelif@yahoo.com 
underwent a tru-cut biopsy and histopathology was reported as mixoid spindle cell tumor revealing mixoid liposarcoma. Keeping this report in view; the patient was recommended total excision of the retroperitoneal mass. In the intraoperative observation the close relation of the tumor with the adjacent peripheral nerve was remarked.

Postoperative macroscopic outlook was a mixed solid and cystic mass with hemorrhagic surface. Microscopic slices revealed a well capsulated lesion including cystic and hemorrhagic areas. Pathologic diagnosis was reported as ancient schwannoma (Figure $2 \mathrm{a}-2 \mathrm{~b}$ ).

Treatment: The patient was recommended observation without any adjuvant treatment. She is free of recurrence in postoperative 4th month.

\section{Discussion}

\section{Epidemiology-Clinical Features}

Schwannomas or neurilemmomas are benign soft-tissue

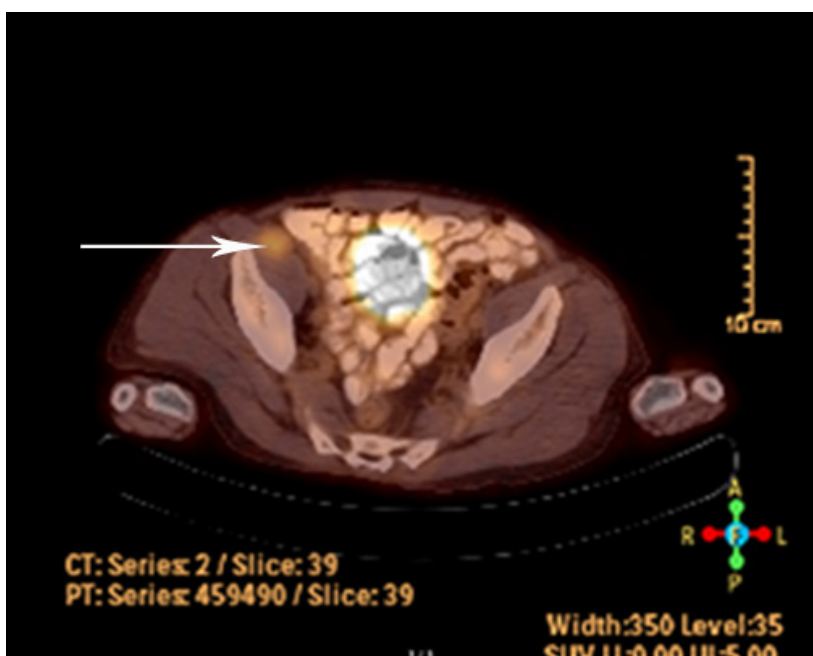

Figure 1a. Axial image of PET scan. Lesion is marked with black arrow.

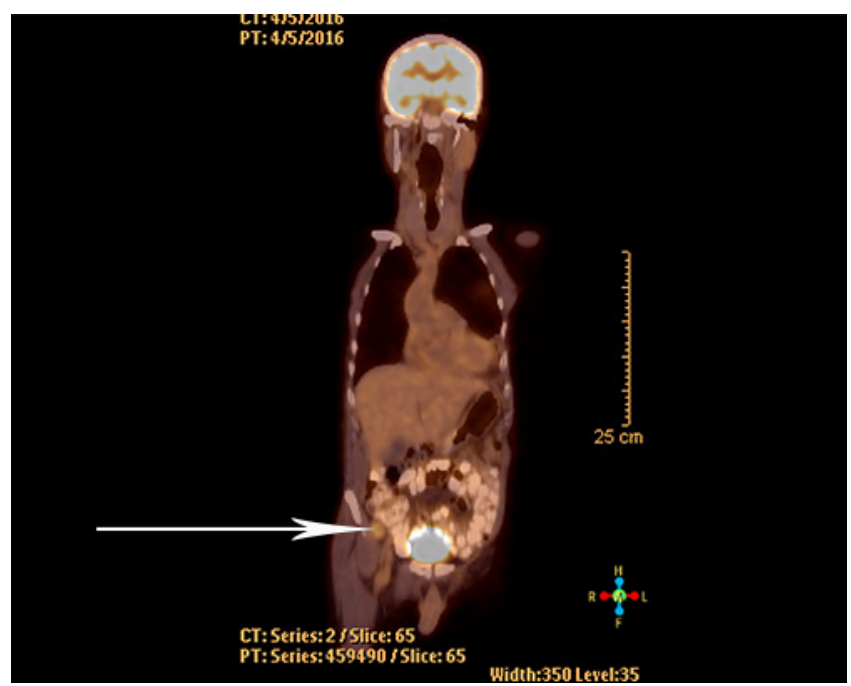

Figure 1b. Coronal image of PET scan. Lesion is marked with black arrow. tumors, which arise from Schwann cells of the peripheral nerve sheaths. They are commonly originated from head and neck and the extremities (4) Retroperitoneal schwannomas account for $0.3 \%$ to $3.2 \%$ of these tumors (5)

Ancient schwannoma is a rare variant of schwannoma first described by Ackerman and Taylor in 1951. The term 'Ancient' verbalize characteristic hypocellular and degenerative areas which is believed to ocur with the long term progression of the tumour. 3 . They constitute $0.8 \%$ of all soft-tissue tumors (6). Patients are mostly diagnosed between ages 40 and 60 years and the ratio between men and women is $2: 3(7)$.

Most cases are asymptomatic and incidentally discovered during medical examination or imaging. Infrequently they can cause pressure effects on surrounding large nerves (8). A recent study on clinical features of retroperitoneal schwannoma also confirmed that symptoms were nonspecific, and neurologic symptoms were rare (9). Those nonspesific symptoms can be hypertension, abdominal pain, flank pain,

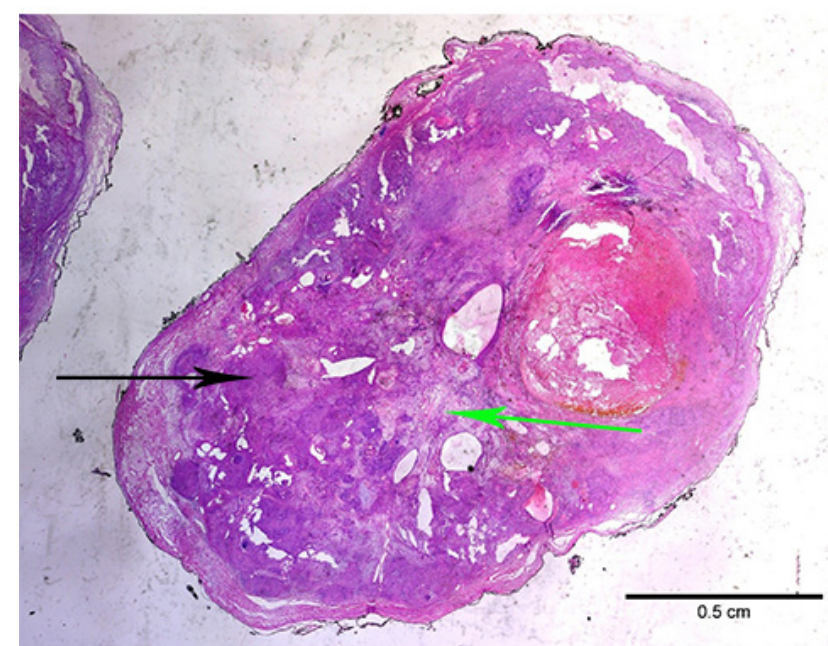

Figure 2a. $\mathrm{H}$ and $\mathrm{E}$ stained tumor showing the characteristic Antoni $\mathrm{A}$ and $\mathrm{B}$ areas $(\times 10)$

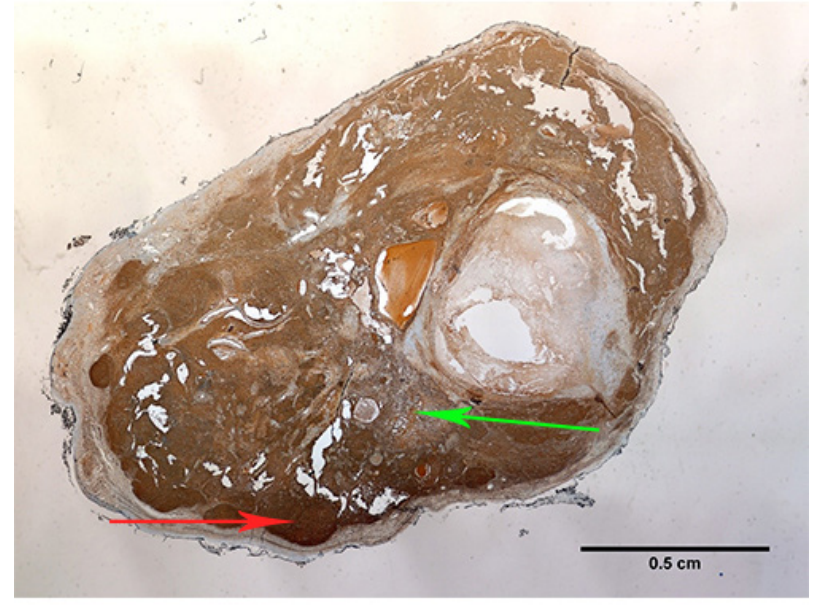

Figure 2b. S100 stained tumor showing the characteristic Antoni A and $\mathrm{B}$ areas $(\times 10)$ 
renal colic pain, hematuria and headache (7).

Mostly, due to the large loose areolar space, the clinical course is slow and and malignant change is uncommon (10).

\section{Radiologic Findings-Diagnosis}

Although ancient Schwannoma may exhibit some certain radiologic features, due to absence of pathognomonic ones 13 preoperative diagnosis is challenging in these cases.

In ultrasonography lesion is seen as a well-defined, solitary and oval or sphere-shaped mass with regular contours that is hypoechogenic or of mixed echogenicity. (5).

CT scans can reveal low or mixed attenuation. Cystic changes due to central cystic necrosis, are common in retroperitoneal schwannomas according to other retroperitoneal tumors. Density in CT-scan depends on the lesional rearrangements which can be cystic, necrotic, haemorrhagic or in the form of calcification. Pure cystic forms are also reported (11). CT-scan provides a better analysis of the bone extension,. Besides, the opportunity of wide field examination with the adjacent vital organs enabling spatial analysis is the major advantage of CT scan in terms of pre-surgical evaluation of patient (5).

MRI provides better visualization in terms of tumor's origin, vascular architecture, and involvement of surrounding organs in large retroperitoneal tumors (9), in other words, the tissue analysis is better with MRI (5). In MRI, the association of a T1 isosignal at the adjacent skeletal muscle, with a T2 hypersignal is reported frequently however it is non-specific. T2 signal intensity is inversely proportional to the cellularity of the tumour. So, Antoni type B which is hypocellular is associated with intense T2 hypersignal. The contrast enhancement shows tissue portions, partitions, septa and walls of the lesion. High intensity of rearrangements reveals more heterogeneous contrast enhancement (12).

Some authors advocate angiography for assessment of vascularisation in the tumour and/or evaluate presurgical embolisation (13).

CT-guided biopsy and fine-needle aspiration are reliable methods of diagnosis for retroperitoneal schwannomas (8). Presence of heterogeneity and areas of degeneration on CT or MRI, cause a suspicion of malignancy. Therefore obtaining tissue diagnosis before embarking on surgical resection is recommended (14).

CT-guided biopsy works if sufficient Schwann cells for microscopic visualization is obtained. This procedure is not supported as a diagnostic tool by many investigators who based their contest on the risks of hemorrhage, infection, and tumor seeding (2). Duodeno-pancreatic sphere technically provides a good and efficient alternative, especially for the small lesions (under $3 \mathrm{~cm}$ ) (12).

Efficacy of fine needle aspiration cytology(FNA)is not well established, while cellular pleomorphism leads to misinterpretetion as malignancy (2) In more complicated cases above mentioned biopsy techniques fail, preoperative incision biopsy was advocated as an alternative by some authors. However these preoperative diagnostic procedures can be omitted in some cases while the tumor mostly has an intact smooth capsule, without any adjacent organ involvement despite the radiologically demonstrated heterogeneity raising the probability of malignancy (15). The differential diagnosis of retroperitoneal schwannomas includes neurofibroma, paraganglioma, pheochromocytoma, liposarcoma, malignant fibrous histiocytoma, lymphangioma, and hematoma (9).

\section{Histopathologic Features}

These tumors are macroscopically encapsulated and histologically includes dense, highly cellular Antoni A areas, and loose Antoni B areas of myxoid stroma (10). Predominat degenerative findings such as cystic degeneration, fibrosis, stromal edema, xanthomatous change, and perivascular hyalinization are some of the histologic patognomonic features $(7,10)$. Pleomorphism, lobulation, or hyperchromasia due to degenerative nuclear changes are also common (6) Plenty of theories raised in an attempt to explain this degenerative process. One theory is degeneration of Antoni B areas leading to cyst formation while growing, a second one advocates central ischemic necrosis due to increasing tumor causing cysts within the tumor (16).

\section{Treatment Considerations-Prognosis}

Primary treatment of choice for retroperitoneal schwannoma is complete excision in healthy patients. If not feasible, partial or subtotal resection can be done to protect adjacent organs or neurovascular structures, although tumour recurrence may be inevitable in such cases (17). Controversy on this issue is proceeding especially when adjacent tissue or viscera is to be sacrificed for clear margins. Some investigators impose complete excision, if necessary, taking the risk of sacrifice of adjacent tissue (2). Others advocate more conservative surgical procedures like simple enucleation or partial excision accepting they are sufficient. After intralesional enucleation reported local recurrence rates range from $16 \%$ to $54 \%$ (7). Some other studies reported recurrence rates ranging from nonexistent to greater than $50 \%$ with simple enucleation (18). Complete surgical resection is recommended because frozen section analysis is not adequate to exclude malignancy (7). Considering the frequent concern for malignancy with ancient schwannoma due to the heterogeneous appearance on imaging, radical excision is usually the recommended treatment in these situations (19).

Laparoscopy is also safe and effective alternative modality for schwannomas, offering better visualization in narrow anatomic spaces. Although successful laparoscopic resection even near the great vessels has been described there may be an increased risk of hemorrhage, leading to unsuccessful resection or intraoperative mortality. Laparoscopic resection of larger tumors $(>5 \mathrm{~cm})$ may entail longer hospital stays than even with open resection (2).

Prognostic behaviour of ancient schwannomas are similar to other schwannomas. Absence of mitoses and preservation of spindle shaped cells can be helpful for differentiation from malignancy. Complete surgical resection with preservation of the surrounding structures mostly ensures cure in these patients (19).

\section{Conclusion}

We presented a case of an unusual pathological entity, retroperitoneal ancient schwannoma. These are slow growing, clinically indolent behaving benign tumors, which 
may present with pressure symptoms in some cases. Surgical resection provides cure.

Retroperitoneal schwannomas are usually identified incidentally on tomographic images. Diagnosis is based on histopathological examination after surgery and immunohistochemical examination. Total excision of the tumor had the best prognosis.

\section{References}

1. Choudry HA, Nikfarjam M, Liang JJ, Kimchi ET, Conter R, Gusani NJ, et al. Diagnosis and management of retroperitoneal ancient schwannomas. World J Surg Oncol 2009;7:12.

2. Daneshmand S, Youssefzadeh D, Chamie K, Boswell W, Wu N, Stein JP, et al. Benign retroperitoneal schwannoma: a case series and review of the literature. Urology, 2003, 62(6):993-997.

3. Loke TK, Yuen NW, Lo KK, Lo J, Chan JC. Retroperitoneal ancient schwannoma: Review of clinico-radiological features. Australas Radiol 1998;42:136-8.

4. Jayaraj SM, Levine T, Frosh AC, Almeyda JS. Ancient schwannoma masquerading as parotid pleomorphic adenoma. J Laryngol Otol 1997;111:1088-90.

5. Hughes MJ, Thomas JM, Fisher C, Moskovic EC. Imaging features of retroperitoneal and pelvic schwannomas. Clin Radiol 2005;60:886-93.

6. Ackerman LV, Taylor FH. Neurogenous tumors within the thorax; a clinicopathological evaluation of forty-eight cases. Cancer 1951;4:669-91.

7. Cury J, Coelho RF, Srougi M. Retroperitoneal schwannoma: case series and literature review. Clinics (Sao Paulo). 2007;62:359-362.

8. Hide IG, Baudouiu CJ, Murray SA, Malcolm AJ. Giant ancient schwannoma of the pelvis. Skeletal Radiol, 2000, 29(9):538-542.

9. Goh BK, Tan YM, Chung YF, et al. Retroperitoneal schwannoma. Am J Surg. 2006;192:14-18.
10. Giglio M, Giasotto V, Medica M, Germinale F, Durand F, Queirolo G, et al. Retroperitoneal ancient schwannoma: case report and analysis of clinico-radiological findings. Ann Urol (Paris), 2002, 36(2):104-106.

11. Von Figura G, Hartmann D, Pauls S, Barth TFE, Adler G,Henne-Bruns D, et al. Difficult diagnosis of a large cystic retroperitoneal tumor mimicking a hepatic origin. $\mathrm{Z}$ Gastroen-terol 2010;48(11):1301-4.

12. Kudo T, Kawakami H, Kuwatani M, Ehira N, Yamato H, Eto K,et al. Three cases of retroperitoneal schwannoma diagnosedby EUS-FNA. World J Gastroenterol 2011;17(29):3459-64.

13. Hoarau N, Slim K, Da Ines D. CT and MR imaging of retroperitoneal schwannoma. Diagn Interv Imaging. 2013 Nov;94(11):1133-9.

14. Schindler OS, Dixon JH, Case P. Retroperitoneal giant schwannomas: report on two cases and review of the literature. J OrthopSurg (HongKong) 2002;10(1):77-84.

15. Al Skaini MS, Haroon H, Sardar A, Bazeed M, Al Zain A, Al Shahrani M et al. Giant retroperitoneal ancient schwannoma: Is preoperative biopsy always mandatory? Int J Surg Case Rep. 2015;6C:233-6.

16. Kim P, Ebersold MJ, Onofrio BM, Quast LM. Surgery of spinal nerve schwannoma. Risk of neurological deficit after resection of involved root. J Neurosurg, 1989, 71(6):810814.

17. Pongsthorn C, Ozawa H, Aizawa T, Kusakabe T, Nakamura T, Itoi E. Giant sacral schwannoma: a report of six cases. Ups J Med Sci 2010;115(2): 146-52.

18. Gubbay AD, Moschilla G, Gray BN, Thompson I. Retroperitoneal schwannoma: a case series and review. Aust N Z J Surg. 1995;65:197-200.

19. Wollin DA, Sivarajan G, Shukla P, Melamed J, Huang WC, Lepor H. Juxta-adrenal Ancient Schwannoma: A Rare Retroperitoneal Tumor. Rev Urol. 2015;17(2):97-101. 